\title{
S. Khojanov and the Phenomenon of National Communism in Central Asia and Kazakhstan in the 20-Ies. XX Century
}

\author{
Abikey Arman Muratuly ${ }^{1} \&$ Tursun Hazretaly $^{1}$ \\ ${ }^{1}$ A. Yasawi International Kazakh-Turkish University, Turkestan, Kazakhstan \\ Correspondence: Abikey Arman Muratuly, A. Yasawi International Kazakh-Turkish University, Turkestan \\ 161200, Kazakhstan. Tel: 7-701-210-4936. E-mail: abikey.arm@mail.ru
}

Received: September 14, 2013

Accepted: November 25, 2013 Online Published: December 29, 2013

doi:10.5539/ass.v10n2p93

URL: http://dx.doi.org/10.5539/ass.v10n2p93

\begin{abstract}
This article tells about phenomenon of national communism in Central Asia and Kazakhstan in the 20-ies, XX century on the example of the politician was Sultanbek Khojanov. S. Khojanov was one of the notorious national communists, who left a bright mark in the history of the Soviet Central Asian Republics and Kazakhstan. S. Khojanov's main activity, as a national communist, traces back to 1920-1925; that is, when the republics of the Soviet type were created in the Soviet East. As a former representative of the opposition to the tsarist regime, and later-to Bolshevism, Khojanov joins the Bolshevik Party after defeat of the opposition, actively protecting the interests of indigenous people.

Due to the acute shortage of educated people among indigenous people, as well as due to his active work, Khojanov finds himself in the top echelons of power of the Turkestan ASSR in a short time. He was the head of the People's Commissariats for Internal Affairs, Education, and Agriculture during the period from 1920 to 1924. He also became a deputy chairperson of the Central Executive Committee of the Turkestan Autonomous Soviet Socialist Republic. After disengagement of TASSR, he was appointed the Second Secretary of the Regional Party Committee of the Kazakh SSR in September 1925.

Under his leadership, the year 1921-1922 was held in Turkistan land reform. As a result of reforms in favor of the indigenous inhabitants of the land were seized Russian immigrants captured during the colonization of tsarist Russia.

The culmination of his political activity has become a social and political activity in Kazakhstan, where clearly expressed its position as a national-communist.
\end{abstract}

Keywords: the February Revolution, October Revolution, Bolshevism, National Communism, Central Asia, Turkestan, Kazakhstan

\section{Introduction}

At the beginning of the XX century, the Russian Empire survived a number of major blows, and in the end was thrown into turmoil of two succeeding revolutions of 1917. Illegal political organizations, advocating the overthrow of the tsarist autocracy and the establishment of a democratic republic, became more active. The wind of change was also felt by the colonial East. But the indigenous people of the colonial East were not formed socialist party. Only with the indulgence of the Tsarist regime in the province, have come into being national-liberal movement.

However, they struggle with the Bolsheviks during the years of the Civil War, led to their military and political defeat. Kokand autonomy was destroyed in Turkestan and the government of Alash in Kazakhstan. The province has established Soviet power.

Summing up what has been said, the members of the Alash movement in Kazakhstan who fought against the Bolshevik Party, as well as those in the Kazakh regions of Turkestan, after their defeat joined the construction of Soviet society at a local level. But the Bolsheviks did not allow them to party leadership. They were allowed to work only in the sphere of science and education. However, some young supporters of the Alash movement, joining the ranks of the Communist Party, were able to move into the higher echelons of power. It is these people, related to the Alash movement, who assiduously promoted the principles of the nationality policy, as they were trying to connect the ideas of national liberation with the 
ideas of Marxism and communism. Soon Stalin bureaucracy will begin to call them "national communist". One of the notorious nationalist-communists of Central Asia and Kazakhstan was Sultanbek Khojanov.

\section{S. Khojanov in the Ranks of National and Bourgeois Intellectuals}

The last years of study Sultanbek Khojanov trace back in pre-revolutionary years. Taking revolutionary mood of the time into consideration, Sultanbek Khojanov took part in clandestine organizations in 1915-1917. A famous telegram sent to the newspaper of Alash Orda-"Kazakh"-reveals its essence, "We are ready to take the lead of the strong army" (Khojanov, 1917) a kind of the cry of a young patriot. Undoubtedly, the development of Khojanov's political outlook was influenced by his numerous meetings with such personalities as Miryakub Dulatov and Mustafa Chokay during the years of adolescence, who were among the originators of the Kazakh national movement. In other words, it is before the October revolution that he had an opportunity to learn about the ideas of the "Alash" national movement, about the restoration of statehood on the basis of Kazakh autonomy, and later join this movement as an active protagonist of autonomy in the south. We can see his position in relation to other political forces on the pages of "Birlik Tuy" ("The banner of unity"), which he began to publish together with Mustafa Chokay in August 1917.

We believe, in the article "Our Bolsheviks" S. Khojanov expressed a common view of the bourgeois intelligentsia on the evolving political situation during the February Bourgeois Revolution. "Now the Russian government is helpless, as it is struck with a terrible disease. A true name of the disease is ignorance, a false name is Bolshevism. The current state of Russia is obvious both to those with vision and without. Having gone mad in consequence of the disease, it is drinking its own blood, eating its own flesh. It is no longer Russia it used to be. All its resources replenished until now, its culture-everything turns to dust, flows away like water. The Social Democratic Party is a party that appeared in Europe. For this reason its program was written taking into consideration the lives of the people in Europe. One cannot compare the bourgeoisie and proletariat of Europe with our wealthy people-the owners of thousands of herds-and orphaned paupers.

The draft reforms proposed by it are a folly much like helping a premature baby out. Recently, one of them, named Trotsky, said in his speech, "We are going to carry out these great changes as an experiment in Russia." And indeed it is their true goal. Knowing that it won't work in Russia, they think, "We'll try at least; we have nothing to lose." That is why the majority, who are not indifferent to the fate of Russia, are against these reforms with all their heart (Khojanov, 1918). Against the background of stagnation of the bourgeois government, the rapid growth of political activity of the Bolsheviks worried not only the western world, but also the entire colonial East.

Khojanov's article "Russian congresses in Turkestan" clearly states his political stance. It is obvious that he supported constructive relationships between the political forces, calling for observance of legitimacy when accomplishing any political actions. While local political forces, within legitimacy were looking forward to the Constituent Assembly, the Bolsheviks sought to take power into their own hands. In his articles, the young S. Khojanov attacked the unscrupulous policy of Bolshevik, criticized and condemned them for their chauvinism to indigenous people. The major point of not recognizing the autonomy by the Bolsheviks was that it was apparently not what the poor region needed. In his articles, young S. Khojanov attacked the Bolsheviks with their unprincipled politics, criticized and condemned them for their chauvinism to indigenous people.

Alikhan Bukeikhanov, the leader of the "Alash" movement, declaimed against the radical nature of the Bolsheviks' actions in "Kazakh" newspaper, "After Nikolay abdicated the throne, the only hope and support for people, except for God, was a Constituent Assembly. But the Bolshevik, lifting his leg relieved himself on the head of the Constituent Assembly" (Bukeikhanov, 1918).

An attempt of Turkestan people to revive the national statehood on the basis of democratic principles was completed when the Bolsheviks captured Kokand in February 1918, a stronghold of Turkestan government. The capture was accompanied by bloodshed of both soldiers and civilians. "Birlik Tuy", headed by S. Khojanov, commented on the elimination of Turkestan autonomy as follows: "It (the Soviet government-AA.) has recently sprinkled the streets of Kokand with human blood, leveled the old city populated by Muslims, killed thousands of defenseless Muslims, looted all their property, not under its usual banner, but under the red one, not with its usual slogan, but under the name of freedom and revolution" (Khojanov, 1918).

S. Khojanov edited "Birlik Tuy" until April 1918. He was a herald of the independence of Turkestan to the last, until the declaration of the Turkestan Autonomy. After the establishment of the Bolshevik regime, S. Khojanov, being out of the party, was actively involved in the solution of problems of the region for three years. It was at this time when huge famine which killed more than a million Kazakhs broke out in Turkestan. S.Hodjanov wrote about this terrible situation in the penultimate issue of "Birlik Tuy", "The deplorable state of Kazakhs of the 
Turkestan region is close to critical. The nation faces a risk of extinction. Streets are flooded by Kazakhs emaciated with hunger. Every other face is swollen from hunger. Wherever I look, there are dead bodies everywhere. At this time, there is neither a possibility nor force to take them away. No one knows how it will end. At this rate it is uncertain if there will remain any Kazakhs in Turkestan. People's hopes of relief in the near future are disappearing unless God makes a move. No activities are fighting for the life of the dying, and there is no crop ripened crop. What may lie ahead?! (Khojanov, 1918). Active in nature, S. Khodjanov did not restrict himself to writing articles appealing for help to the hungry. By agreement with the management board of "Birlik Tuy" the Committee for Famine Relief was organized, which, in its turn, organized a meal station (Sharip, 2009).

S. Khojanov's desire to help his people to a greater extent in the circumstances concerned induced him to join the ranks of the Communist Party, all the more so because, as a member of no party, he often had to deal with the arbitrariness of local party officials. So, from the very beginning of his career in the Bolshevik regime, Khojanov was accused of being a Menshevik, counter-revolutionary, and nationalist.

S. Khojanov had to join the ranks of the Communist Party in March 1920. Nevertheless, from then on he started his rapid movement up the party ladder. S. Khojanov's high level of education for those times in view of extreme domestic labour shortage in the country explains his quick ascent in government structures.

Thus, in September 1920 at the Fifth Congress of the Communist Party of Turkestan, he was elected a member of the Executive Bureau of the Central Committee. And as early as at the Ninth Congress of Soviets of the Turkestan Republic, he was elected a member of the Presidium of the Central Electoral Commission of Turkestan. In government he successively held the posts of the People's Commissar for Internal Affairs, Education, Agriculture and Deputy Chairperson of the Central Executive Commission of Turkestan. In November 1924 he took up a post of the second secretary of the Kazakh Regional Committee of the Communist Party of the Russian Soviet Federative Socialist Republic (b) in the Kazakh SSR. It should be noted that since 1920, holding positions of higher responsibility, he concurrently held the position of an editor of "Ak Jol"-a mouthpiece of the Central Committee of the Communist Party of Turkestan.

\section{S. Khojanov'S Political Activity in Turkestan}

In difficult conditions of economic and social situation in Turkestan, there were such crucial problems to solve as development of national education and indigenous land management. It is in these areas that from 1921 to 1924 Khojanov took the lead of an activity at first at the Commissariat for Education and then at the Commissariat for Agriculture. It is interesting that the written reference to the Central Committee of the Communist Party of Turkestan (1922, November) describes S. Khojanov as a person who: "is not well grounded in theory with narrow-minded views regarding the national question. He grew up under the influence of complicated conditions of Kyrgyz (Kazakh) nomadic life. He is a political demagogue playing on the Kyrgyz people's tribal feelings. It is better to use him in print, in the editing of the Kyrgyz press" (Keldiev, 1996). Thus, it's clear that Khojanov was not a dedicated Bolshevik, but a nationalist. We mention this fact because even though the Central Committee of the Communist Party of Turkestan, condemned Khojanov, it still let him take over the commissariats, which were the most problematic and the most decisive in solving problems of indigenous people of Turkestan. It should be pointed out that, they did not work in an established country with its own history, but in a completely new one, where they were the creators. That is why these conditions required self-confident political figures that were able to take the initiative in their hands. Khojanov was one of those politicians who, following the directives of the party brought in those adjustments which addressed the specifics of the Republic.

S. Khojanov, being a teacher, was familiar with the deplorable state of the education system of Turkestan. Thus, in order to combat illiteracy of the local population, many schools were built in the post-revolutionary Turkestan, but they were not backed up with appropriate facilities. The People's Commissariat for Education under the leadership of S. Khojanov presented a program of public education at the XI Congress of Soviets of Turkestan in December 1922. This program made provisions for a number of reductions of administrative staff of the Commissariat. In most areas it was necessary to register public education institutions once again, find out their condition, and clarify the need for school buildings and teachers. Taking into account the major need of the native population in education, he insisted that, "Congress must express its authoritative decision for the provision of enhanced state percentage of the state budget for educational needs" (Bulletin of the Eleventh All-Turkestan Congress of Soviets, 1922).

The course on full reduction of the national and local administrative staff of the Commissariat was carried out by the board of the People's commissariat for education. Delegates of the Ninth Congress of Soviets took into account the scarcity of financial support and an acute shortage of teaching staff and approved the course. They also approved the establishment of a mandatory network of educational institutions of all grades, allocated 
depending on the state and local budget funds, the increase of allocations for public education to be from 14 to $20 \%$ of the total budget of the Turkestan.

S. Khojanov kept on insisting on the increase of Turkestan budget for education of indigenous people at the IXth All-Russian Congress of the Soviets in Moscow (1921). At this congress during the break S. Khojanov met Vladimir Lenin. V. I. Lenin called him "the hot-tempered Kyrgyz (Kazakh)", for his performance on questions of education of indigenous people of Turkestan. S. Khojanov's fruitful activity in the National Commissariat of education was stated in the document under the name "Job evaluation. Khojanova, on a position the National commissariat of education of the republic of Turkestana".

"Comrade Khojanov has been working at this position since October 1921. He has been its actual leader for the entire period of his work. He has great energy and initiative, combines work in his department with the general objectives of the state, has an exceptional ability to select employees and executives, and he is persistent in carrying out the planned tasks. He is indispensable for the People's commissariat for education in Turkestan conditions. Apart from his primary job, Khojanov holds the post of People's Commissar for Agriculture, where he showed himself as a good leader as well, as the one who knows the conditions of Turkestan." (TsGRAUz, F. 60, Opis' 2, delo 296, list 17).

From what has been said, apart from the Commissariat for Education, Khojanov was concurrently in control of the Commissariat for Agriculture, which was no less complicated at that time considering the economic and social life of the Turkistan society. Poor development of capitalism and the maintenance of feudal-patriarchal relations in agriculture determined the specific character and the rate of the revolutionary agrarian transformations, which were slower than those of Central Russia. In 1918, only the land of the tsar's family, officials, the wealthiest bais, and individual agricultural and industrial capitalist associations was confiscated. But the foundations of colonial Russia in the republic were still strong. Native people were still not involved in the construction of the new society. The unresolved problem of landlessness in the Soviet East made a conflict situation worse. This was facilitated not only by historical factors, but also by the fact that during the period of anarchy in the 1920s "Russian land ownership" in Kazakhstan increased even more. In1918-1922 when devastation and famine struck the country, a stream of impoverished landless peasants flooded Central Asia. Since the new government announced a slogan "Land to the peasants!", it illegally seized land available. As a result, by the mid 20's Slavic population together with Germans amounted to more than 2.2 million people in Kazakhstan (Chebotareva, 2008).

The complication of the situation in the East was also caused by the fact that after the victory of the October Revolution the majority of Kazakhs refugees (1916) returned to Semirechye from China in 1918-1920, hoping to regain lost land. But wealthy Cossacks and kulaks did not give up their positions, impeding return of the land, livestock and the property looted.

That is why the next major step of the agrarian reform was the Land Reform of 1921-1922, which was carried out on the basis of the resolution of the Central Committee of the RKP (b), dated July 29, 1920, and the decisions of the Fifth Congress of the Communist Party of Turkestan and the Ninth All-Turkestan Congress of Soviets. The main aim of the reform was to give the local and Russian peasantry equal rights to land. Lands which had been seized by Russian kulak settlers were handed over to the native population. The Land reform was carried out in the main areas of colonization in the Turkestan ASSR: Semirechensk, a number of counties of the Syr Darya and Ferghana region.

It should be noted that the reform and the preparation for it were carried out in accordance with the Soviet laws under very controversial circumstances. The arrangements for the reform, which were necessary in 1921, were to be completed before spring field work. That's why there was an extreme lack of time. Besides there was a serious lack of land surveyors, and those who were there were all Russian, who did not wish to participate in the Land Reform. All these difficulties explain why the land reform, implemented by the party, has been later criticized. However, in the eyes of the middle-level local people the justice was served. Thus, according to the results of the commission, which implemented the Land and Water Reform and which was guided by the instructions of the People's Commissariat for Agriculture of Turkestan, 161 Russian villages and 175 farms, 95 winter huts and 35 separate occupied territories were destroyed in Semirechye. Of these 8,084 farmsteads were evicted and 232,891 desyatinas of land were seized (AP RK. F.139, Opis' 1, delo 109, list 2).

But the reform was not carried through. As mentioned above, the Russian peasantry, being essentially the colonizers, did not want to give the land back to the local people of the region. The complaints from Semirechensk Cossacks and peasants started coming to the center immediately. There were particularly many people displeased with measures, taken by S. Khojanov, who was in charge of land reform. On the basis of these 
complaints, the conclusion was drawn that there were some mistakes made while carrying out the reform. In order to calm the nascent national enmity between the settlers and native population, the center started adopting directives on the interruption of the reform process. The Land reform in Semirechye received such publicity that even V. I. Stalin had to intervene. On his behalf, the Asian Bureau received a telegram with the following contents: About two weeks ago, the Central Committee of the RKP (b), while satisfying the request of the Asian Bureau and a member of the Central Committee-Rudzutak-in a special telegram ordered Khojanov's Commission to immediately stop evictions in Semirechye. Today Rudzutak's telegram has arrived, which states:

"Even though Khojanov was summoned to Tashkent three times, he refused to leave Semirechye under various excuses and continues with the evictions..." The Central Committee of the RKP (b) orders the Asian Bureau of the Central Committee to take all measures for immediate cessation of the evictions in Semirechye and prosecute the guilty for violating the directive of the party. The Central Committee of the RKP (b) orders the Asian Bureau to summon Khojanov and send him to Moscow for an explanation. The measures taken and Khojanov's departure should be reported to the Central Committee." (AP RK. F. 811, Opis' 24, delo 243, list 1).

After that S. Khojanov's commission was withdrawn from Semirechye under an excuse that "international principles in national policy of the party have been violated."

\section{S. Khojanov and the Demarcation of the Central Asian Republics in 1924}

It was decided to launch a campaign of national-state demarcation of the Soviet Republics of Middle Asia in 1924 in Moscow.

The national-state demarcation involved the territorial rearrangements of the Turkestan ASSR, the Bukhara People's Soviet Republic and the Khorezm People's Soviet Republic. The separate republics were to be made of major ethnic groups: Kazakhs, Uzbeks, Turkmens who lived in the region. Two northern regions of Turkestan, Syr Darya and Djetisuysk inhabited by Kazakhs became part of the Kazakh ASSR. It was also planned to create Autonomous Regions out of such minorities such as Kara-Kyrgyz, Tajiks and Kara-Kalpaks.

However, among the statesmen of Turkestan were those who had an opposite opinion. Their leader was S. Khojanov. They are called to unite instead of dividing the Central Asian Federation. Despite the overall disposition to demarcation, S. Khojanov, did not think highly of it. The position he held at that time shows that he really fought for overcoming all those obstacles that were left by tsarist Russia. Turkestan had only started recovering from the uprising of 1916 and the famine of 1921-1922 in 1924, perceiving the positive role of the New Economic Policy. In these circumstances, he believed the forthcoming demarcation would be a step back for further social and economic development of the region. Besides, there was already an example when the republics formed a federal state within the USSR. S. Khojanov proposed the formation of the Central Asian Federation, following the example of the Transcaucasian Soviet Federative Socialist Republic.

He thought that the people of Turkestan might create the national republics, but might not do without economic unity. From his point of view, the project of the Central Asian Federation as a single unified national state was based on the historical territorial and economic affinity. A member of the Asian Bureau of the Central Committee of the RCP (b), O.Karklin, Latvian by birth, supported this project. He pointed to the need for preservation of the existing economic ties, represented by the Economic Council, between the republics of Central Asia. A number of Kazakh party officials demanded that Kazakh regions join the Kazakh SSR and offered to make it part of the Central Asian Federation (Ismailov, 2006). The Chairperson of the Central Asiatic Economic Council, M.A.Paskutsky, proved his viewpoint concerning the project by the need for the "political and economic unity."

However, the alternative to the demarcation was dismissed. In 1924-1925 as a result of the national-state demarcation the territory of Turkestan, Bukhara and Khorezm republics was rearranged into: the Uzbek and Turkmen SSR, the Tajik ASSR as a part of the Uzbek SSR, and the Kara-Kirghiz Autonomous Oblast of the RSFSR. The Karakalpak Autonomous Oblast and parts of the Turkestan ASSR, inhabited by Kazakhs, became part of the Kazakh ASSR.

S. Khojanov, who offered the idea of the Central Asian Federation, was labeled as a "pan-Turkist." However, hardly anyone nowadays doubts the importance of integration.

\section{S. Khojanov's Political Activity in Kazakhstan}

A special extraordinary session of the Turkestan Central Executive Committee convened on 15-16 September 1924 to discuss and approve the plans for the delimitation of TASSR, which meant the dissolution of the Republic. A group of the Kazakh party officials from Turkestan headed by Khojanov took part at the plenum of the Kazakh regional committee in Orenburg on September 26, 1924. Making a speech on behalf of Turkestan Kazakhs, Khojanov sharply criticized Kazakh regional committee for being not sufficiently active in the 
campaign of the demarcation. He also speaks about the nationality policy in the country, considering its work to be highly dissatisfactory.

Khojanov constantly criticized the problem of the nationality policy in KASSR on the pages of "Ak Jol" long before this plenum. Being among the people who, as it seemed, were the chief policy conductors, he nevertheless got a negative reaction on the part of both European and Kazakh representatives, which forced him to come out with a strong statement:

"The problem is that we often forget the nationality question, whereas Europeans are the ones who particularly must know that while working in the national republics, they must not only keep it in memory, but also emphasize it when discussing these or other issues. In this respect, I am not very satisfied with the speeches of comrades Yezhov and Bakh. In the end, the situation is exactly as described by comrade Yezhov and if a number of comrades made some more speeches, we would eventually come to such division of labor that is needed on this issue, and namely that the Kyrgyz (Kazakh) communists should moderate chauvinistic attitudes, and European-colonialist. Then we would have a harmony. And again we say to those who do not want to understand it, "Get out of the KSSR" (AP RK. F.139, Opis' 1, delo 816, list 80).

Continuing this theme, in October of the same year he wrote to Stalin: «No matter how, the European population in Kazakhstan is $54 \%$ of the total population, while only $46 \%$ of Kazakhs. In an organization of the RKP (b) of Kazakhstan, the Kazakhs make up 6\% (368 people), and they are scattered on party divisions» (AP RK. F.141, Opis' 1, delo 1129, list 80).

The solution to this situation, as he systematically shows, is the prompt transfer of the center of the republic into the southern region, which is densely populated by the Kazakhs. This is clearly expressed in the following letter to Stalin, written in December 1924: «The oddity that the Kyrgyzs (Kazakhs) in their own country have a position of national minority is necessary to get rid of. The proletarian leadership should not be held in order to capture Kyrgyz parties of intelligent people in the proletarian center as Orenburg, but should be held in the living mass work instead. Proletarian leadership is not facilitated by a quantitative increase of the Russian peasants in the population, but it is rather complicated by aggravation of the traditional ethnic hatred and the inevitable assessment of the proletarian leadership impact as Russian national dominance. The proletarian leadership should not be expressed by the stagnation, but by the expanded, developing economic and social life of the country» (AP RK. F.141, Opis' 1, delo 1129, list 79).

After justifying and reconciling the further actions of the leadership of the Republic, Khojanov begins to build a «working environment» within the Secretariat and the government. It excites a petition before the Central Committee-On registration of the rights and responsibilities of the Secretariat of the Kazakh District Committee of the Russian Communist Party. As a result, in Secretariat places are distributed: Naneyshvili 1st Secretary, Khojanov 2nd Secretary, Yezhov 3rd Secretary (AP RK. F.141, Opis' 1, delo 10, list 2).

Activity of Khojanov at that time was due to the fact that in the face of Naneyshvili-the First Secretary of Kazkraykom, he found a kindred spirit. Before replacing Naneyshvili with Goloshekin, this political duo acted very well. For further offensive work it was necessary to neutralize a combat of the groups at the government. Thus, at the threshold of V-Kazakh Congress of Soviets, he neutralizes the left group, under the supervision of Mendeshev-the Chairman of the Central Executive Committee (CEC). At the meeting of the Kazkraykom Bureau (7/IV. 1925), Munbaev was appointed as a head of the Central Election Commission, instead of Mendeshev.

The seriousness of the fighting factions in the government is described in the following document written by Khojanov in the Bureau of Regional Committee of the RKP (b): "In my absence, this May 19, a decision on the composition of the Bureau of Regional Committee was issued and among other things, the majority opinion on the abandonment of Comrade Mendeshev in the Bureau was admitted. The main trouble in the practice of the Regional Committee, until now, was that its Bureau, designed to carry out the fundamental tasks of the plenum of the Central Committee and the Regional Committee of the RKP (b), was a kind of combination of various democratic groups and essentially consisted of a coalition of the groups, and it was not a working body of the Regional Committee.

Now we have entered a period of hot practical work on the internal construction of Kazakhstan, and what was tolerable in the former congestive specific environment, cannot be tolerable now. We will have to establish its center, creating a truly unified Republic of Kazakhstan, acting towards internal improvement of the Republic, taking urgent practical steps towards the service entirely Kazakhstan. Now facing those problem and tolerate grouping, allow mutual surveillance, panache the superiors of the administration, arrange the failure of the private business, which is in the hands of a hostile group of people-all these would be just criminal. Comrade 
Mendeshev in the eyes of the masses, first of all was a Soviet figure, who was appointed five consecutive years as a chairman CEC. He was painlessly fired from his position and no one was surprised by this case. It would seem that in order to eradicate the group difficulties in Regional Committee a comrade Mendesheva should be removed from the membership of the Bureau, and a new Chairman of CEC named Munbaev should have been introduced instead. In such a case it would be, at least, of the one most intransigent group the less and the possibility of practical work would have increased, instead of endless fights and intrigues against each other. Concerns of the comrades that Mendeshev will, once and forever, reject the group austere were not serious in my opinion. I think that the best guarantee is not the words but eradicated of those opportunities.

By leaving the former situation as it was, I consider it as a desire to maintain the status quo and as a desire not to improve it. I believe that the time for comrades Europeans has come into power when they have, at least to some extent, to run the risk and rely on some part of the Kyrgyz (Kazakh) workers, and together with them carry out the urgent work, and stop forever the completion between different groups for individual satisfaction and play a crucial role, only taking an advantage of developed disagreement rather than principled governing. As one of the practical steps in this direction, I consider that the following is appropriate: 1) to increase the number of members of the Regional Committee of the Bureau to 9, and then to 7 ( 3 in the Headquarter and 4 in representation offices); 2) to appoint comrade Munbaev instead of Mendesheva and Dzhandosov instead of Kuletov; 3 ) to have 2 secretaries as on the example of the other republics of the National Central Committee: one European and one Kyrgyz (AP RK. F.141, Opis'1, delo 10, list 5).

Thus, due to the full support of the first secretary of Kraykom comrade Naneyshvili, Khojanov was able to make some progress in inter-group struggle to bring like-minded people in responsible positions, thereby creating the conditions for fruitful work. He succeeds in the short term, to move the capital to the south of Kazakhstan in the city of Ak-Mosque and there to hold the V-th All-Kazakh Congress of Soviets, for the first time in the newly merged Kazakhstan. The Congress outlined the principal positions in the government. On the agenda of the Congress there were such questions as: land management and irrigation, public education, trade and co-operation, the financial situation in Kazakhstan, etc. At this particular congress the capital of Ak-Mosque was renamed in Kyzyl Orda-Red Headquarter, historical name of indigenous (local) folk of the republic such as Kazakhs was returned. Previously, mistakenly, they were calling themselves Kyrgyzs. However in politics of Kazakhstan cool changes were coming. In July Moscow withdraws Naneyshvili, and in August instead of him sends Goloshekin.

Khojanov, initiated an environment of active work in the Republic, cannot work together with Goloshekin, as the new protégé of Moscow, as subsequently it becomes known, he was unquestioning executor of Center. Without taking into account the specifics of the Republic, and who was regardless of the opinion of the national communists. Knowing Khojanov since his work in Turkestan Commission, Goloshekin realizes that he could not easily carry instructions from Moscow. So in October, during his visit to Stalin, he seeks withdraw of Khojanov to Moscow at the disposal of the Central Committee of the RCP (b). After getting rid of Khojanov, Goloshekin, he experiences resistance from other national communists in the face Munbaev (Chairman of CEC) and Sadvokasov (Commissariat). So, for the removal of nationals who have their own point of view in solving various problems, Goloshekin accuses the «behavior, performance and epy strategy of a group of comrades-Khojanov, Munbaev and Sadvokasov» at the III-rd Plenum of VKP (b) Kazkraykom. On this basis the official campaign against the national communists begins, denoting their previous activities in Kazakhstan as «khojanov» and «sadvokasov» movement (AP RK. F.141, Opis' 1, delo 1129, list 77).

Later, Khojanov writes a letter to the Kraykom regarding the groundlessness of the plenum decisions, condemning him in belonging to the opposition, as well as for active participation in the «khojanov-sadvokasov» group. But he admits that during campaigns he had nationalist ideas in carrying out such campaigns as: elimination of residues of the colonial regime, land reform, national delimitation, moving the center of KSSR, etc. At the end of the letter he stated to Stalin about his willingness to give up his mistakes (AP RK. F.141, Opis' 1, delo 1129, list 91).

At that time Khojanov, who was an exchange student on the course «Marxism and Leninism» in Moscow understands that this campaign can prevent his eventual return to Kazakhstan. In March 1927, Khojanov held a meeting with Stalin. Which resulted in a letter of Stalin to Goloshekin: «On one of these days comrade Khojanov has turned to me with the complaint that the comrades of Kazakstan accuse him in sympathizing with or belonging to the opposition and asked me to express my opinion. I readily agreed to it, saying to him that I have absolutely no reasons to accuse him in sympathizing with, and even more of belonging to the opposition in the CP. I know that Khojanov has residues of internationalist outlook. I know that these residues are not only academic, but also practical, which have been once expressed in a certain group fighting in Kazakstan. But this fact certainly does not give us the reason to accuse Khojanov in sympathy or in belonging to the opposition. 
And in a conversation with me S. Khojanov didn't deny the presence of nationalist basis in his work in Kazakstan. He expressed his willingness to give any statement to the press or in any other form that he was willing to give up his mistakes. I have no doubt that he will reinforce his commitment with his work immediately, if required by Kraykom. I think that the Regional Committee should help him in this matter. If the Regional Committee is pleased, I'm ready to render any assistance from my side. With communistic greetings, Stalin» (RGASPI, F.558, Opis' 11, delo 133, list 89).

In December 1927, after completion of the course on «Marxism and Leninism», Khojanov, finding himself completely rehabilitated for Kazkraykom and Stalin, refers to Kazkraykom Bureau of the VKP (b) with his willingness to work: «In November 1926 at the 3rd Plenum of the Regional Committee, I was accused, at my absence, for the nationalistic ideas and the group related actions in the past.

For the purpose of rehabilitation, I wrote an explanation and tried to correct my mistakes. Now I graduated from the courses. And I have the opportunity to correct my mistakes practically, in fact, to prove my loyalty to the party line and the ability to work without grouping and without nationalism.

My statement on 10 August 1927 Kraykom was ecognized as a step to rectify. Of course, a rectification shouldn't be in words, but in deeds instead. And it has to be done no where else but in Kazakstan. I need to stand the test of the party and to demonstrate my loyalty to exactly in a place where these errors were committed and where these accuses have been stated.I am confident that Kraykom will give me this opportunity.

On 9th March this year, in the letter to Goloshekin, about me, Comrade Stalin wrote: «He is willing to give up his mistakes. I have no doubt that he will reinforce his commitment with his work immediately, if required by Kraykom. I think that the Regional Committee should help him in this matter».

On the VI All-Kazakh Conference of the VKP(b) comrade Goloshekin, in respect of the permissibility to use me in Kazakstan, said: «I believe that it is acceptable, but not on managerial position, assigning him to any other position and take a good look a year».

I appreciate this comradely attentive attitude to me by comrade Goloshekin. In this I realize the assistance of the Regional Committee which was mentioned by Comrade Stalin. I am willing to undergo this test. I ask to give me this opportunity, appointing me for a job either in the office or in the Regional Committee (Kraykom) or at the Regional Soviet Party School such, so I could undergo this test under the direct supervision of Kraykom. In addition to that my personal and family circumstances force me to move to the south (in Central Asia), and my desire to have two years of work with the books makes me to apply for a job on the line of Soviet Party School. S. Khojanov. December 6, 1927 Moscow» (AP RK. F.141, Opis' 1, delo 1129, list 102).

However Kazkraykom found it impossible to provide Khojanov with a work in Kazakhstan. Especially in view of the forthcoming collectivization he was not a convenient figure. As it turned out he was no longer destined to return to Kazakhstan. He was directed to Central Asian Bureau, which has entrusted only a position of a deputy director of agitprop (campaign) department. After removal of Khojanov from the Republic, Goloshekin gets rid of the other national communists, leaving next to him only the obedient to his will and never arguing nationals. Khojanov, appointed by the 1st Secretary of Ukraine-Kaganovich, almost at the same time with Goloshekin, despite the conflicts, still was able to work together with such national-communists as A.Shumsky and N.Skripnik. Due to this, the base for the development of ukrainianization was established, which do not interfere a further curtailment of the national policy in the 30s. In the method of the work of Goloshekin with national communists in Kazakhstan the voluntarism has prevailed. Consistent support of Goloshekin from the Center in his fight against national communists, is due to the fact that in Kazakhstan the land issue-land management of Kazakhs has not been resolved. That support eventually had to affect the success in holding of the national policy. The policy of gradual subsidence of the Kazakh people was not stipulated by the party. This fact explains the contradictions that arose between the party and national communists. But the administration headed by Goloshekin didn't consider it necessary to solve the problem of gradual, painless settling of Kazakhs and to take into account the arguments of the national communists. This would be the basis of the national policy. As it is known the party was willing to see prompt results. By 1928, Goloshekin having reached his autocracy, devoted to his method of working, will lead a campaign of collectivization. As it is known in a result of collectivization famine that engulfed the whole of Kazakhstan. People of Kazakhstan had to endure Goloshekin to 1933. By this time, Kazakhstan will lose half of its population.

\section{Conclusion}

The phenomenon of national communism was developed, where there were strong remnants of the colonial relation. The region of Central Asia was heavily exposed to colonial relationship, which led to a strong 
manifestation of national communism. Promising slogans of Bolsheviks already in the Soviet East took root extremely difficult because of resistance of the Russian immigrants. Bolsheviks from indigenous people proved national communist in this fight. They fought for the enforcement of what the Bolsheviks promised in theory. They had clear ideas about the sorry state of development of indigenous people. Therefore, in their social and political activities are not dominated by international influences and vice versa national motives. These motives are clearly shown in such large-scale campaigns as: elimination of the remains of colonial relation, land reform of 1921-1922, delimitation of Central Asia etc. However their national biases become the main tool of their political opponents, than it will skillfully use for removal of national communist from political arena.

\section{References}

AP RK. (Archive of the President of the Republic of Kazakhstan). F. 139, Opis' 1, delo 109, list 2. (F. 139, Inventory 1, File 109, Sheet 2).

AP RK. F. 139, Opis' 1, delo 816, list 80.

AP RK. F. 141, Opis' 1, delo 10, list 2.

AP RK. F. 141, Opis' 1, delo 10, list 5.

AP RK. F. 141, Opis’ 1, delo 1129, list 102.

AP RK. F. 141, Opis' 1, delo 1129, list 77.

AP RK. F. 141, Opis' 1, delo 1129, list 79.

AP RK. F. 141, Opis' 1, delo 1129, list 80.

AP RK. F. 141, Opis' 1, delo 1129, list 91.

AP RK. F. 811, Opis' 24, delo 243, list 1.

Biulleten XI Vseturkestanskogo siezda Sovetov. (1922). (Bulletin of the XI-th All-Turkestan Congress of Soviets) (p. 17). Tashkent.

Bukeikhanov, A. (1918). Gazette, Kazakh.

Chebotareva, V. G. (2008). Natsional'naia politika Rossiiskoi Federatsii 1925-1938 gg. (National Politics of Russian Federation in 1925-1938 y) (p. 505). Moscow: GUMDN.

Ismailov, A. I. (2006). Iz istorii iujnih oblastei Kazahstana: 1917-1925 gg. (From the history of the Southern Regions of Kazakhstan: 1917-1925 y) (p. 116). Shimkent: Askarali.

Keldiev, I. (1996). Istoricheskii opit reshenia problem rukovodiysh'ih kadrov v usloviah Srednei Azii v pervie godi Sovetskoi vlasti. Avtoreferat na soiskanie uchenoi stepeni. (Historical experience in solving the problem on administrative personnel in terms of Central Asia, in the first years of Soviet regime. Auto report for seeking a scientific degree) (p. 37). Dushanbe: Tau.

Khojanov, S. (1917, March 24). Telegram. Gazette, Kazakh.

Khojanov, S. (1918, April 9). Turkistannan. Gazette, Birlik Tuy.

Khojanov, S. (1918, February 20). Ozimizdin Bolsheviksingender. Gazette, Birlik Tuy.

Khojanov, S. (1918, March 16). Kokan. Gazette, Birlik Tuy.

RGASPI. (Russian-State Archive of social-politic history). F.558, Opis' 11, delo 133, list 89. (F. 558, Inventory 11, File 133, Sheet 89).

Sharip, A. (2009). Shigarmalari. S. Kojanuly. (Works. Khojanov, S) (p. 295). Almaty: Aris.

Stalin, I. (1951). Sochinenya (Essayy) (Vol. 5, p. 305). Moscow.

TSGARUz. (Central State Archive of the Republic of Uzbekistan). F.60, Opis' 2, delo 296, list 17. (F. 60, Inventory 2, File 296, Sheet 17).

\section{Copyrights}

Copyright for this article is retained by the author(s), with first publication rights granted to the journal.

This is an open-access article distributed under the terms and conditions of the Creative Commons Attribution license (http://creativecommons.org/licenses/by/3.0/). 